\title{
DO FUNCIONAL AO SIMBÓLICO
}

Alberto Cipiniuk< Dr.

Pontifícia Universidade Católica do Rio de Janeiro, PUC -Rio

acipiniuk@gmail.com

Matheus Cannone

Pontifícia Universidade Católica do Rio de Janeiro, PUC -Rio

Mariana Ribeiro Meirelles

Pontifícia Universidade Católica do Rio de Janeiro, PUC -Rio

Mariana Flamenbaum

Pontifícia Universidade Católica do Rio de Janeiro, PUC -Rio

Suelen Felix da Silva Batista

Pontifícia Universidade Católica do Rio de Janeiro, PUC -Rio

Resumo: O objetivo dessa pesquisa é definir a identidade do objeto industrial contemporâneo, compreendendo como e por que ocorre a sua ressignificação. Entendemos que do início da Revolução Industrial até os anos noventa do século $X X$, os fatores que definiam a identidade de um objeto industrial eram a qualidade da usinagem e os "novos" materiais empregados. Nos dias de hoje por consequência de duas grandes circunstâncias - o acirrado reagrupamento das grandes indústrias e das prestadoras de serviços de todos os tipos (venda de serviços em geral, financeiras, produção de bens industriais etc.) no denominado capitalismo flexível e de outra parte a globalização dos meios de comunicação, os antigos esteios identitários foram desfuncionalizados e estão sendo ressignificados. Esse processo de ressignificação é construído socialmente e nossa intenção é definir quais são as circunstâncias sociais que nele atuam formando o Campo do Design, isto é, produção, recepção e circulação dos objetos industriais. Partindo de um seminal artigo de Arjun Appadurai em 1986, nossa modesta proposição é aproximar os objetos da sua vida social. Enfim, acompanhar a biografia dos objetos, identificar como eles são usados e reutilizados assim como as transformações de sua ontologia, contudo, sempre considerando que essas metamorfoses são indissociáveis da vida social das pessoas, pois essas alterações de significação, são também àquelas da vida dos homens. Desejamos investigar as relações humanas com os objetos nos espaços domésticos e públicos, isto é, nas instituições de legitimação e consagração. Entendemos que os objetos são 
- lugar de mobilização dos indivíduos para redefinir o seu uso e sua significação. Atualmente os bolsistas de Iniciação Científica estão estudando o projeto de pesquisa aprovado pelo CNPq para estar em vigor pelos próximos três anos. Suas atividades são: compreensão do escopo teórico da pesquisa, debates e leituras paralelas. Do mesmo modo estão identificando os agentes sociais aos quais aplicarão de um questionário, posto que um questionário piloto já foi aplicado no final do ano passado durante a Semana de Design no Rio de Janeiro. Nos próximos três anos outros bolsistas seguirão os passos desse grupo, em outras etapas que serão desdobradas nessa pesquisa.

Palavras-chave: design, objeto industrial, função, simbólico, ressignificação 